\title{
THE NUREMBERG TRIAL: Procedural Due Process at THE INTERNATIONAL MILITARY TRIBUNAL
}

\author{
Tessa McKeown*
}

For over 60 years, lawyers and historians have discussed the credibility and repercussions of the Nuremberg Trial (1945-1946). The Nuremberg Trial at the International Military Tribunal was conducted by the four Allied Powers to try the upper echelon Nazi war criminals following the Second World War. The London Charter, drafted by the Allies, outlined the trial procedure to be adopted, and provided certain guarantees in an attempt to secure a fair trial for the 22 defendants. This article examines the history of fundamental due process rights (recognised in both Continental Europe and Common Law jurisdictions) and analyses the extent to which these rights were breached at Nuremberg. It argues that the defendants' procedural due process rights were partially protected at Nuremberg, although there were gross breaches of particular fundamental due process rights. This article further argues that despite the defendants being afforded more rights than they could have expected given the circumstances, such breaches significantly compromised the integrity of the trial.

\section{INTRODUCTION}

The Allied victors of the Second World War wrote the London Charter (the Charter) establishing the International Military Tribunal (IMT) to try the upper echelon Nazi leaders. The due process rights of the 22 Nazi defendants were partially protected at Nuremberg, although there were gross breaches of particular fundamental rights, which compromised the integrity of the trial. However, given the unique historical and political context of the trial and the limited practical alternatives available, the Nazi defendants were arguably afforded more due process rights than they could have expected.

The defendants' right to a public trial was upheld at Nuremberg. All of the defendants were represented by counsel, though they were deprived of the opportunity to represent themselves. The

* Article submitted as part of the LLB(Hons) programme at Victoria University of Wellington. The author would like to thank Dr Grant Morris for his invaluable supervision. 
independence of the Tribunal can be criticised, though arguably this did not detract from its ability to remain impartial. The grossest breaches of due process rights lay, first, in the lack of adequate time and facilities to prepare and present a defence, and secondly, in the deprivation of the right of appeal. These and other fundamental due process rights will be discussed in the context of the main Nuremberg Trial at the IMT.

While the retrospective application of law at Nuremberg is repeatedly criticised by lawyers and historians, this issue will not be dealt with in this article. The focus of this article is on the less frequently discussed due process rights accorded to the Nazi defendants during the trial itself, and the extent to which these rights were breached.

\section{BACKGROUND TO NUREMBERG}

Following the end of World War II, the Allied Powers were faced with the decision of what to do with the captured German war criminals. Three courses were open to the Allies: release, summary execution or trial. ${ }^{1}$ The Soviets were in favour of summary execution, an option that received initial support from Churchill. ${ }^{2}$ Opinion surveys carried out in Britain and the United States of America indicated that the majority of public opinion was in favour of execution without trial of the upper echelon Nazi leaders. ${ }^{3}$ Henry L Stimson, United States Secretary of War, advocated for a trial, stating that the "moral position" of the Allies would be thrown into question if they conformed to Nazi methods and carried out execution without the protection of law. ${ }^{4}$

On 8 August 1945, the United States, the United Kingdom, France and the Soviet Union (Allies) signed the Agreement for the Prosecution and Punishment of the Major War Criminals of the

1 Matthew Lippman "Nuremberg: Forty Five Years Later" in Guenael Mettraux (ed) Perspectives on the Nuremberg Trial (Oxford University Press, New York, 2008) 492 at 522; Charles Anthony Smith The Rise and Fall of War Crimes Trials from Charles I to Bush II (Cambridge University Press, New York, 2012) at 85; Henry L Stimson "The Nuremberg Trial: Landmark in Law" (1947) 25 Foreign Aff 179 at 179; Aaron Fichtelberg "Fair Trials and International Courts: A Critical Evaluation of the Nuremberg Legacy" (2009) 28 Crim Just Ethics 5 at 7; Michael R Marrus The Nuremberg War Crimes Trial 1945-46: A Documentary History (Bedford Books, Boston, 1997) at 242-243.

2 Otto Kranzbuhler "Nuremberg Eighteen Years Afterwards" in Guenael Mettraux (ed) Perspectives on the Nuremberg Trial (Oxford University Press, New York, 2008) 433 at 444; Mark Aarons "Justice Betrayed: Post-1945 Responses to Genocide" in David A Blumenthal and Timothy LH McCormack (eds) The Legacy of Nuremberg: Civilising Influence or Institutionalised Vengeance? (Koninklijke Brill, Leiden, 2008) 69 at 70 .

3 Fichtelberg, above n 1, at 7; Marrus, above n 1, at 242; Gary Jonathan Bass Stay the Hand of Vengeance: The Politics of War Crimes Tribunals (Princeton University Press, New Jersey, 2000) at 199.

4 Marrus, above n 1, at 244; Stimson, above n 1; Lippman, above n 1, at 552. 
European Axis Powers (London Charter). ${ }^{5}$ Article 1 of the Charter established the IMT, which was to sit at the Palace of Justice in Nuremberg, Germany. The Allies selected the defendants because each was the highest-ranking individual in his area or department. ${ }^{6}$ One defendant committed suicide; another was considered not fit to stand trial, leaving 22 defendants to be tried.

The Tribunal was made up of four members: one voting judge selected from each of the four Allied powers, and each with an alternate. Lord Justice Lawrence (United Kingdom) was the President of the Tribunal. Francis Biddle (United States), Professor Henri Donnedieu de Vabres (France) and Major General Iona Nikitchenko (Soviet Union) made up the remainder of the Tribunal. The Tribunal's authority was unchallengeable. According to the Tribunal, its jurisdiction came from the Charter, which was created by the Allied Powers as a result of its rights and powers over the nations that had unconditionally surrendered to the Allies. ${ }^{7}$

Article 16 of the Charter aimed to protect the due process rights of the accused. Justice Robert Jackson, chief prosecutor for the United States, recognised the importance and necessity of securing a just trial for the 22 defendants. In his opening statement he declared: ${ }^{8}$

[W]e must never forget that the record on which we judge these defendants today is the record on which history will judge us tomorrow. To pass these defendants a poisoned chalice is to put it to our lips as well.

Despite these noble intentions, the existence and protection of the defendants' due process rights at Nuremberg is still contested.

\section{DUE PROCESS: THE CONCEPT AND ITS APPLICATION AT NUREMBERG}

The concept of due process is based upon equality and basic fairness, the Common Law origins of which stem from the Magna Carta, ${ }^{9}$ and were further developed in the English Bill of Rights

5 The Agreement for the Prosecution and Punishment of the Major War Criminals of the European Axis Powers is accessible via Yale Law School "The London Charter of the International Military Tribunal 1945" The Avalon Project: Documents in Law, History and Diplomacy < avalon.law.yale.edu>.

6 Smith, above $\mathrm{n} 1$, at 82 .

7 Andreas Krieg "The Nuremberg Trials: An Attempt of Bringing War Criminals to Justice" (2009) The Pica Project <www.thepicaproject.org $>$ at 6.

$8 \quad$ Nuremberg Trial Proceedings (21 November 1945) vol 2 at 100.

9 Magna Carta 1297; John Hostettler Champions of the Rule of Law (Waterside Press, Hampshire, 2011) at 64; DJ Galligan Due Process and Fair Procedures (Oxford University Press, New York, 1996) at 171. 
1688. While there are some differences between jurisdictions as to exactly what procedural due process is comprised of, there is a general consensus as to the basic elements. ${ }^{10}$

Common Law and Civil Law jurisdictions have different criminal procedures and different standards of due process. Common Law states follow an adversarial trial procedure, emphasising the equality of arms between the parties, the right to cross-examination and the right to counsel. ${ }^{11}$ Equality of arms is the concept that requires both the prosecution and the defence to have a reasonable opportunity to present their case at no disadvantage vis-à-vis the other side. Civil Law procedure (as used in Continental Europe) is inquisitorial. The focus is on the pretrial phase and emphasises judicial participation in the proceedings. ${ }^{12}$ When drafting the Charter, both systems necessarily had to be regarded. Justice Jackson observed the difficulty in this: ${ }^{13}$

Members of the legal profession acquire a rather emotional attachment to forms and customs to which

they are accustomed and frequently entertain a passionate conviction that no unfamiliar procedure can

be morally right.

The procedural rules adopted were an amalgamation of Anglo-American and Continental European systems, though they were predominantly based on the American model. ${ }^{14}$ Stimson argued that a combination of both systems allowed for and protected the defendants' rights under both. ${ }^{15}$ This compromise allowed the trial to proceed efficiently. ${ }^{16}$

10 Joel M Gora Due Process of Law (National Textbook Company, Illinois, 1979) at xi; David J Bodenhamer Our Rights (Oxford University Press, New York, 2007) at 116.

11 Caroline Buisman "Defence and Fair Trial" in Roelof Haveman, Olga Kavran and Julian Nicholls (eds) Supranational Criminal Law: A System of Sui Generis (Antwerp, New York, 2003) 167 at 169.

12 At 169 .

13 Phillipe Kirsch "Applying the Principles of Nuremberg in the International Criminal Court" (2006) 6 Wash U Global Stud L Rev 501 at 505.

14 Evan J Wallach "The Procedural and Evidentiary Rules of the Post-World War II War Crimes Trials: Did They Provide an Outline for International Legal Procedure?" (1998-1999) 37 Colum J Transnatl L 851 at 854; Stimson, above n 1, at 186; Richard May and Marieke Wierda "Trends in International Criminal Evidence: Nuremberg, Tokyo, The Hague and Arusha" (1998-1999) 37 Colum J Transnatl L 725 at 728; Kirsch, above n 13, at 505; Hans Ehard "The Nuremberg Trial Against the Major War Criminals and International Law" (1949) 43 AJIL 223 at 226; H Wechsler "The Issues of the Nuremberg Trial" (1947) 62 Polit Sci Q 11 at 13.

15 Stimson, above $\mathrm{n} 1$, at 186.

16 Whitney R Harris Tyranny on Trial: The Evidence at Nuremberg (Southern Methodist University Press, Dallas, 1954) at xxxv. 


\section{THE RIGHT TO COUNSEL}

\section{A History and Development}

A defendant's right to counsel is viewed as one of the most fundamental rights accorded to accused people in criminal trials, in both Continental and Common Law jurisdictions. Before the 19th century in Civil Law jurisdictions, it was generally the judge who examined the evidence, requiring little support from the defendant and their counsel. ${ }^{17}$ During the 19th century, the role of the accused developed and thus required the defence to undertake a more active role in proceedings. It was during this period that the right to counsel became an important legal right in Civil Law jurisdictions. ${ }^{18}$ English Common Law did not provide a defendant with the right to counsel until 1836, however this guarantee is now considered one of the most fundamental rights offered to criminal law defendants. ${ }^{19}$

The right to counsel is viewed as an important component of an accused person's basic due process rights. ${ }^{20}$ This is also true in the international sphere. A defendant's right to consult counsel and seek representation ensures that a defendant is treated fairly throughout the proceedings. ${ }^{21}$ The presence of counsel is a means of reducing power imbalances between defendants and the state, and of securing the right to equal justice. ${ }^{22}$

\section{B Application and Extent to which the Right was Breached at Nuremberg}

Article 16 of the Charter secured the defendants' right to counsel. ${ }^{23}$ If a defendant failed to appoint counsel, the Tribunal would do so for him. ${ }^{24}$ Only one lawyer was permitted to appear at

17 Sarah J Summers Fair Trials: The European Criminal Procedure Tradition and the European Court of Human Rights (Hart Publishing, Oregon, 2007) at 79.

18 Summers, above n 17 , at 79 .

19 Bodenhamer, above n 10, at 173; Kent Roach Due Process and Victims' Rights: The New Law and Politics of Criminal Justice (University of Toronto Press, Toronto, 1999) at 88; Alexander Zahar and Goran Sluiter International Criminal Law (Oxford University Press, New York, 2008) at 309; Geoffrey Palmer and Matthew Palmer Bridled Power: New Zealand's Constitution and Government (4th ed, Oxford University Press, Melbourne, 2004) at 328.

20 Akhil Reed Amar The Constitution and Criminal Procedure: First Principles (BookCrafters, Michigan, 1997) at 90; Philip A Joseph Constitutional \& Administrative Law in New Zealand (3rd ed, Thomson Brookers, Wellington, 2007) at 180.

21 Palmer and Palmer, above n 19, at 328.

22 Summers, above n 17, at 82; Gora, above n 10, at 37; Palmer and Palmer, above n 19, at 328.

23 Article 16(d).

24 "Rules of Procedure for the Trial of the German Major War Criminals 1945" Nuremberg Trial Proceedings vol 2, r 2(d). 
the trial for any defendant (in absence of special permission from the Tribunal). ${ }^{25}$ The defendants' right to conduct their own defence was expressly provided for in the Charter. However, when Rudolf Hess stated that he was actually prepared to do so, this right was ignored. ${ }^{26}$ All of the defendants were represented by counsel. ${ }^{27}$

The Tribunal established a secretariat office to manage the trial's administration. British officer, Major Neave, served the defendants with the indictment and offered assistance in finding counsel. ${ }^{28}$ Neave explained to the defendants their rights under the Charter. ${ }^{29}$ One month prior to the eve of the trial, Neave presented the defendants with a list of 60 suitable lawyers and legal professors to select from. ${ }^{30}$ Alternatively, the defendants were entitled to request counsel of their choosing, who then had to be approved by the Tribunal. ${ }^{31}$

All chosen counsel were prominent German lawyers and professors. ${ }^{32}$ Almost half of the defence counsel had Nazi backgrounds - some even "ardent and unrepentant" Nazis. ${ }^{33}$ Six were in fact proven to have been members of the Nazi Party. ${ }^{34}$ Major General Nikitchenko and Lieutenant Colonel Volchkov (the Soviet alternate) voted against the acceptance of these six as counsel, however the other Tribunal members outvoted them. ${ }^{35}$ The Tribunal never rejected those chosen as counsel. This leniency is evidence of the Tribunal's efforts to provide the best possible opportunity for the defendants to present their defences.

25 "Rules of Procedure for the Trial of the German Major War Criminals 1945" Nuremberg Trial Proceedings vol 2, r 2(d).

26 Werner Maser Nuremberg: A Nation on Trial (translated by Richard Barry, Penguin Books, London, 1977) at 73.

27 Arthur L Goodhart "The Legality of the Nuremberg Trials" in Guenael Mettraux (ed) Perspectives on the Nuremberg Trial (Oxford University Press, New York, 2008) 626 at 629; Brian Orend The Morality of War (Broadview Press, Peterborough, 2006) at 171.

28 Robert E Conot Justice at Nuremberg (Harper \& Row Publishers, New York, 1983) at 78.

29 Lord Justice Lawrence "The Nuremberg Trial" (1947) 23 J Intl Aff 151 at 151-152.

30 Conot, above n 28, at 78; Bradley F Smith Reaching Judgment at Nuremberg (Basic Books, Michigan, 1977) at 82.

31 Eugene Davidson The Trial of the Germans: An Account of the Twenty-Two Defendants Before the International Military Tribunal at Nuremberg (University of Missouri Press, Columbia, 1997) at 30.

32 Stimson, above $\mathrm{n} 1$, at 186 .

33 Stimson, above n 1, at 186; Conot, above n 28, at 83.

34 Maser, above n 26, at 74.

35 At 74 . 
The Allies covered defence counsel's expenses. They were paid, fed, housed and provided with offices and assistants. ${ }^{36}$ While some counsel had supported Nazism, others opposed it and considered it to blame for all of Germany's present suffering. ${ }^{37}$ Despite this, defence counsel suffered harassment and disrespect by the German public, press and some Allied staff. Counsel were criticised and vilified by reporters of the Nuremberg proceedings. ${ }^{38}$ Further, defence counsel were often treated by Allied staff with the same hostility as the accused, and were made to feel like second-class citizens. ${ }^{39}$

However, the Judges (particularly Lord Justice Lawrence) went to great lengths to ensure defence counsel were respected within the Tribunal and in the media. The Judges recognised that without the assistance of defence counsel, a credible trial would have been impossible. ${ }^{40}$ Lord Justice Lawrence made a point of observing, "In the opinion of the Tribunal, defence counsel have performed an important public duty in accordance with the high traditions of the legal profession." 41 Lord Justice Lawrence criticised Allied occupation powers for allowing press attacks on defence counsel, and stressed that defence counsel were and would remain under the protection of the Tribunal. ${ }^{42}$ The Judges highlighted that further public attacks would not be tolerated by the Court. ${ }^{43}$

Faced with such animosity, acting as counsel for the Nazi defendants was no doubt a task of considerable difficulty. Defence counsel perceived correctly the odds as against them, and were expected to represent their Nazi clients, while not necessarily supporting Nazism themselves. Despite this, counsel often presented clever defences for the accused. Otto Kranzbuhler, counsel for Grand Admiral Doenitz, was considered one of the sharpest defence lawyers during the trial. ${ }^{44}$ Kranzbuhler crafted a defence by presenting an interrogatory to United States Admiral Nimitz that obtained information about United States naval practice. Kranzbuhler used this information to argue that Doenitz's actions were comparable to those of the United States Admiral, and consequently

36 Stimson, above $\mathrm{n} 1$, at 186.

37 Smith, above $\mathrm{n} 30$, at 82 .

38 William Maley "The Atmospherics of the Nuremberg Trial" in David A Blumenthal and Timothy LH McCormack (eds) The Legacy of Nuremberg: Civilising Influence or Institutionalised Vengeance? (Koninklijke Brill, Leiden, 2008) 3 at 8.

39 Smith, above $\mathrm{n} 30$, at 83.

40 Maley, above n 38, at 7-8.

41 Karl Bader "Review" in Wilbourn E Benton and George E Grimm (eds) Nuremberg: German Views on the War Trials (Southern Methodist University Press, Dallas, 1955) 153 at 157.

42 Nuremberg Trial Proceedings (5 March 1946) vol 8 at 532-533.

43 Nuremberg Trial Proceedings (5 March 1946) vol 8 at 531.

44 Maley, above n 38, at 8. 
were in accordance with war at sea practices and therefore not criminal. ${ }^{45}$ Kranzbuhler crafted this argument in a way that could not be rejected as being a prohibited tu quoque ("you, too") defence. This defence was partially successful, and the Tribunal found Doenitz not guilty on count one of the indictment. ${ }^{46}$ While many of the defence counsel presented well-thought out and researched defences, their unfamiliarity with proceedings meant that they were often at a significant disadvantage during the trial.

All German lawyers, defence counsel were acquainted with German legal procedure, and not the Anglo-American trial procedure that prevailed. Defence counsel had to quickly familiarise themselves with the Anglo-American accusatory model. ${ }^{47}$ Given that there was only a 30 day period between the serving of the indictments and the beginning of the trial, counsel would have been primarily focused on looking through evidence and building defences, leaving little to no time to get accustomed to trial procedure. This disadvantaged defence counsel during the trial, and they were criticised for being "clumsy and unimaginative". ${ }^{48}$ First, they were unprepared during crossexamination. ${ }^{49}$ Secondly, they were often unfamiliar with how to handle evidence from interrogatories, as demonstrated in an awkward exchange between Lord Justice Lawrence and Alfred Thoma, counsel for Alfred Rosenberg. ${ }^{50}$

Despite its express protection in the Charter, the defendants were denied the right to act as their own counsel during the trial. When Hess stated that he was prepared to act as his own counsel, this right was ignored. In denying Hess this right, the prosecution was arguably doing him a favour. Hess was exhibiting signs of amnesia and insanity, and any effort made to argue his own case would likely have been compromised, and ultimately ineffective. However, the opportunity to argue one's own case is inherent in the right to counsel. Even when taking into consideration Hess's unusual personal circumstances, this deprivation was a direct breach of the defendants' due process rights.

Therefore, the defendants' right to counsel was partly upheld at the IMT. Defendants were entitled to representation by counsel of their choosing, and counsel were often clever with defences. However, defendants were denied the right to act as their own counsel. Further, counsel's ability to act effectively was partly compromised due to their unfamiliarity with the Anglo-American trial procedure, and the harassment they suffered from the public and press.

45 Nuremberg Trial Proceedings (8 May 1946) vol 13 at 230-245.

46 Participation in a common plan or conspiracy for the accomplishment of a crime against peace.

47 Krieg, above n 7, at 14.

48 Smith, above $\mathrm{n} 30$, at 100.

49 Krieg, above n 7, at 14.

50 Nuremberg Trial Proceedings (15 November 1945) vol 2 at 18. 


\section{THE RIGHT TO A FAIR AND PUBLIC HEARING BY AN INDEPENDENT AND IMPARTIAL COURT}

\section{A History and Development}

A defendant's right to a fair trial is at the heart of criminal proceedings. ${ }^{51}$ While the concept of a "fair trial" often encompasses all due process rights, this article will focus on the more specific interpretation of "fairness" as the notion of equality. ${ }^{52}$

The right to a public trial is a fundamental right of due process. However, in some jurisdictions, this right is not absolute. ${ }^{53}$ In 19th century Continental Europe and England, the requirement of a public hearing was widely contested. By the end of the century, it was a fundamental right in most European legal systems. ${ }^{54}$ The right to a public hearing has many rationales. First, public inspection and criticism of the process provides a sense of legitimacy. ${ }^{55}$ Secondly, it operates as public denunciation of the conduct. Thirdly, it strengthens public confidence in the system by demonstrating the ability of authorities to hold people to account and punish them for their actions. $^{56}$

The concept of an independent trial stems from Montesquieu's 18th century separation of powers theory. ${ }^{57}$ The legislature, executive and judiciary must remain separate to provide checks and balances and prevent abuses of power. Judicial independence is thus of great importance in the context of an international tribunal. This concept should therefore have been borne in mind when appointing tribunal members.

Judges must be impartial in the sense that they must have no preconceived opinions of the defendants and have no stake in the outcome of the trial. Nor should they act in a way that promotes the interests of one party at the expense of the other. A tribunal must operate in absence of prejudice and bias. ${ }^{58}$

51 Zahar and Sluiter, above n 19, at 292.

52 Pascal Chenivesse and Christopher J Piranio "What Price Justice? On the Evolving Notion of 'Right to Fair Trial' from Nuremberg to The Hague" (2011) 24 CRIA 403 at 404; David Feldman (ed) English Public Law (Oxford University Press, London, 2004) at 678-679.

53 Gora, above n 10, at 107.

54 Summers, above n 17, at 39.

55 Summers, above n 17, at 43; Thurman Arnold "Due Process in Trials" (1955) 300 Annals Am Acad Pol and Soc Sci 123 at $124-126$.

56 Summers, above n 17 , at 44 .

57 Charles-Louis de Secondat Baron de Montesquieu The Spirit of the Laws 1748 (translated by Thomas Nugent, D Appleton and Company, New York, 1900).

58 Feldman, above n 52, at 679. 


\section{B Fair Hearing at Nuremberg}

While the right to a fair hearing encompasses many of the rights discussed, it is an important stand-alone right in terms of basic equality, particularly in the context of a post-war ad hoc tribunal such as Nuremberg. Article 16 of the Charter protected the defendants' right to a fair trial by ensuring certain legal procedures were followed. The Allied drafters believed that the inclusion of this Article would "do justice to the defendants" and protect their fair trial rights. ${ }^{59}$ However, art 16 related to "fairness" and due process rights more broadly, and thus this Article will not be the focus of this part. Throughout this part, the concept of fairness will be narrowly interpreted to mean equality.

There is much debate surrounding whether the Nazi defendants received a "fair" trial at Nuremberg. The majority of historical and legal opinion is that given the circumstances, the defendants were given a fair trial. ${ }^{60}$ However, some critics argue that the trial was unfair. ${ }^{61}$ As the concept of fairness is broad and often flexible, such assessments must be approached with caution. Evaluating fairness specifically in terms of equality, this article argues that while inequalities existed between the prosecution and defence, the efforts of the Judges operated to mitigate these inequalities.

The equality of the trial regarding the legal procedure adopted can be questioned. As previously mentioned, the trial ran largely according to Anglo-American legal proceedings - a method unfamiliar to the defendants and to their counsel. This meant that the defence was at a distinct disadvantage vis-à-vis the prosecution. Defence counsel were forced to quickly learn and adapt to the unfamiliar Anglo-American procedure. There was thus no equality between the prosecution and the defence regarding the trial procedure adopted. In fact, the reliance on documentary evidence reflected Continental European legal procedure. However, this actually operated to disadvantage the defence because of the sheer quantity of documents the Allies submitted as evidence. ${ }^{62}$ Given the comparatively short time frame the defence had to deal with the mass of documents and the fewer

59 Krieg, above $\mathrm{n}$ 7, at 7.

60 Maley, above n 38, at 9; HT King "The Judgments and Legacy of Nuremberg" (1997) 22 Yale J Intl L 213 at 221; Jennifer K Elsea Selected Procedural Safeguards in Federal, Military and International Courts (Federation of American Scientists, CRS Report for Congress RL31262, 18 September 2006) at 7; Stimson, above n 1; Carl Haensel "The Nuremberg Trials Revisited" (1963-1964) 13 DePaul L Rev 248 at 258; Jan Schnitzer "The Nuremberg Justice Trial 1947: Vengeance of the Victors?" (LLM Thesis, Victoria University of Wellington, 2010); Orend, above n 27, at 171; Smith, above n 30, at 22-23; Lukman Harees The Mirage of Dignity on the Highways of Human 'Progress': The Bystanders Perspective (AuthorHouse, Bloomington, 2012) at 346; Wallach, above n 14, at 852; May and Wierda, above n 14, at 727; Fichtelberg, above $\mathrm{n} 1$, at 6 .

61 Krieg, above $n 7$.

62 Smith, above n 30, at 83. 
resources the defence had at their disposal to do so, there was no real equality of arms between the parties.

However, the Tribunal attempted to mitigate this inequality by allowing defence counsel to discuss the case with the Tribunal. British alternate, Norman Birkett, argued that it was highly unusual and possibly "very bad" for a court to discuss the case with defence counsel. ${ }^{63}$ Biddle countered: ${ }^{64}$

I don't feel that at all. The great criticism of this trial is going to be that the defendants had very little time to prepare, were not properly represented, that their lawyers labored under impossible difficulties, that they were confused when they went on.

It is therefore important that the Judges recognised the substantial inequality that existed between the prosecution and the defence. The procedures they enacted in attempt to mitigate this inequality are further evidence of the Tribunal's determination to secure a fair trial for the defendants.

The major obstacle in preventing an equality of arms and thus a fair trial was the one-sidedness of the charges. The Nuremberg Trial is widely criticised for not allowing the tu quoque defence, which meant that the Allies could not be charged with the offences they were charging the defendants with, despite having committed them. To prevent Allied acts being called into question, the prosecution based the charges solely on German documentation. ${ }^{65}$ The defendants were prohibited from presenting evidence that implicated the Allies in any war crimes, crimes against humanity or crimes against the peace. ${ }^{66}$ This can be contrasted from Kranzbuhler's framing of Admiral Doenitz's defence as mentioned above. The absence of this tu quoque defence significantly compromised the equality (and therefore fairness) of the trial.

Therefore, the primary barrier preventing an equality of arms between the parties (and thus a fair trial) was that the tu quoque defence was unavailable to the defendants. While significant inequalities existed between the prosecution and the defence in terms of the style of legal procedure adopted during the trial, the procedures enacted by the Tribunal and the efforts of the Judges (particularly Lord Justice Lawrence) operated to mitigate these inequalities.

63 Conot, above n 28, at 86.

64 At 86.

65 Smith, above n 30, at 102.

66 May and Wierda, above n 14, at 761. 


\section{Public Hearing at Nuremberg}

The Nuremberg trials at the IMT were public hearings. In constructing the Palace of Justice to hold the trial, a gallery was built to hold over 250 visitors and members of the press. ${ }^{67}$ The IMT had hundreds of staff who were able to attend the trials, and press and private citizens were given the opportunity to observe the proceedings from the visitor's gallery. ${ }^{68}$ The hearings were open to the German public, and international reporters and visitors had unrestricted access. ${ }^{69}$ The Charter required that copies of the proceedings be made available in multiple languages. ${ }^{70}$

Given that the prosecution relied predominantly on documentary evidence, the audience was largely comprised of counsel, onlookers and correspondents. Encounters with victims and witnesses were therefore unlikely. ${ }^{71}$

Public interest in the trial peaked at the beginning and the end of the trial; during the months in between the gallery was half empty. ${ }^{72}$ The public sessions of the Tribunal continued throughout the trial, however the Tribunal met "behind the scenes" from June until September 1946. ${ }^{73}$ This does not detract from the public nature of the hearings, as private deliberations between judges are expected. Therefore, the defendants' right to a public hearing was upheld.

\section{Independent Tribunal at Nuremberg}

The independence of the Nuremberg Tribunal has been widely criticised. Independence in terms of Montesquieu's separation of powers theory is not usually a concern in international tribunals, because there is no identifiable executive, legislative or judicial body. ${ }^{74}$ The IMT was an ad hoc tribunal, and was governed by one specific Charter drawn up by the Allied Powers for the purpose of prosecuting the Nazi defendants, who were to be tried before a tribunal of judges appointed by the Allies. Thus, the concept of independence will be examined in terms of judicial independence. It

67 United States Holocaust Memorial Museum "The Nuremberg Courtroom" (2013) Holocaust Encyclopedia $<$ www.ushmm.org>.

68 United States Holocaust Memorial Museum "Witnessing History" (2013) Holocaust Museum $<$ www.ushmm.org $>$.

69 Benjamin B Ferencz "Nurnberg Trial Procedure and the Rights of the Accused" (1948) 39 J Crim L and Criminology 144 at 145.

70 Article 25.

71 Susanne Karstedt "The Nuremberg Tribunal and German Society: International Justice and Local Judgment in Post-Conflict Reconstruction" in David A Blumenthal and Timothy LH McCormack (eds) The Legacy of Nuremberg: Civilising Influence or Institutionalised Vengeance? (Koninklijke Brill, Leiden, 2008) 13 at 18.

72 Trial at Nuremberg (directed by Jack Kaufman, Hollywood House Video, 1989); Smith, above n 30, at xiv.

73 Smith, above n 30, at 113.

74 Zahar and Sluiter, above n 19, at 295. 
is therefore important that the Tribunal, as the "judiciary" and the body interpreting the law, maintained independence from the lawmakers.

The Tribunal at Nuremberg was not independent because there was a substantial overlap between lawmaker, prosecutor and judge. Justice Jackson was the primary United States representative in London involved in drafting the Charter. He subsequently played a part in selecting the defendants to be tried, and became the chief United States prosecutor during the trial. Sir Maxwell Fyfe acted in a similar capacity for the United Kingdom. Major General Nikitchenko conducted negotiations for the Soviet Union in regards to the drafting of the Charter, and later sat as the Soviet Union's primary voting Judge on the Tribunal Bench. Robert Falco was the principal French legislator of the Charter, and subsequently sat as the French alternate on the Tribunal. ${ }^{75}$ These overlaps are fundamentally inconsistent with the notion of judicial independence.

Further, not only were there overlaps in the administration of justice at Nuremberg, the law makers, prosecutors and Tribunal Judges were all from the victorious Allied nations. The defence had strong objections against this: ${ }^{76}$

[T] $]$ he defense consider it their duty to point out at this juncture another peculiarity of this Trial which departs from the commonly recognised principles of modern jurisprudence. This one party to the proceedings is all in one: creator of the statute of the Tribunal and of the rules of law, prosecutor and judge.

Defence counsel requested that the Court obtain the expert opinion of internationally recognised international law scholars about the legal foundations of the IMT. The Tribunal rejected this application. ${ }^{77}$ No neutral states or any of the Axis Powers were involved in the drafting of the Charter or sat on the Tribunal Bench. Critics argue that the presence of a neutral nation (such as Switzerland or Sweden) would have enhanced the Tribunal's credibility. ${ }^{78}$ However, many neutral states often affiliated more with either the Allies or the Axis Powers. In light of this, and the postwar political climate, it was arguably not practicable to have a Tribunal composed of any states but those of the victorious Allied Powers.

Therefore, the overlap between the drafters of the Charter, the prosecutors and the Judges, and the fact that all three parts were comprised solely of individuals from the victorious Allied powers considerably compromised the judicial independence of the Tribunal at Nuremberg. However, it is important to recognise that the concepts of independence and impartiality are not synonymous. Independence is primarily concerned with the Tribunal's compilation, whereas impartiality looks to

75 Harris, above n 16, at 498-499; Krieg, above n 7, at 13; Marrus, above n 1, at 250.

76 Nuremberg Trial Proceedings "Motion Adopted by all Defence Counsel" (19 November 1945) vol 1.

77 Nuremberg Trial Proceedings (21 November 1945) vol 2 at 94.

78 Krieg, above $n$, at 13. 
its operation. Consequently, it is possible for one to exist without the other. Therefore, it can be argued that the independence of the Tribunal is not crucial so long as the Tribunal is impartial. ${ }^{79}$

\section{E Impartial Tribunal at Nuremberg}

The Nuremberg Tribunal mostly managed to secure an atmosphere of impartiality. However, the Tribunal's impartiality can be questioned regarding the four victors on the Bench, and also due to existing Tribunal member prejudice. At the opening session of the trial, the four Judges professed, "I solemnly declare that I will exercise all my powers and duties as a member of the International Military Tribunal honourably, impartially, and conscientiously." 80 While great efforts were made to honour this declaration, and such efforts were often successful, the impartiality of the Tribunal remains a contentious element of the trial.

The victorious nations of the War sat on the Tribunal to judge the defeated. United States Senator Robert Taft declared, "The trial of the vanquished by the victors cannot be impartial." 81 The Allies suffered tremendous losses during the war at the hands of the Germans. The argument is that the victors would not be well equipped to judge the German war leaders because they would not be free from "hatred, passion and national prejudice". ${ }^{82}$ As citizens of the victorious nations, the Judges occasionally interacted with members of the prosecution. During the trial, Soviet prosecutor Andrei Vyshinsky came to Nuremberg to sit with the prosecution. While he was visiting, a party was held in his honour, which the prosecution and Tribunal Judges attended. ${ }^{83}$ Such interaction could have made impartiality difficult.

Further, Soviet Judge Major General Nikitchenko openly expressed prejudice toward the defendants. During the London negotiations, Nikitchenko revealed his belief that the purpose of the trial was to determine the appropriate punishment to be given to the Nazi defendants, whose guilt had already been determined. ${ }^{84}$ Such sentiment is indicative of a bias held towards the defendants, and demonstrates that Major General Nikitchenko had adopted a preconceived notion of guilt before having heard any of the evidence. If Major General Nikitchenko was swayed by this preconception, the credibility and impartiality of the Tribunal would have been significantly compromised.

79 Ferencz, above n 69, at 149.

80 Nuremberg Trial Proceedings "Minutes of the Opening Session" (18 October 1945) vol 1; Harris, above n 16 , at 500 .

81 Trial at Nuremberg, above n 72.

82 Karl-Heinz Lueders "The Nuremberg Judgment: Penal Jurisdiction Over Citizens of Enemy States" in Wilbourn E Benton and George E Grimm (eds) Nuremberg: German Views on the War Trials (Southern Methodist University Press, Dallas, 1955) 127 at 135.

83 Davidson, above $\mathrm{n} 31$, at 32.

84 Harris, above n 16, at 499-500. 
However, Major General Nikitchenko was not a main power on the Bench, and he did not carry as significant an influence (relative to Lord Justice Lawrence and Francis Biddle). There is nothing to suggest that his pretrial disposition led him to judge the guilt of the defendants on anything other than evidence presented by both sides during the trial. ${ }^{85}$ With hindsight, the impartiality of the Tribunal may have been better secured had Nikitchenko not gone on to sit as one of the four voting Judges.

The Tribunal's impartiality can further be questioned in relation to the evidential rules of the Charter. Article 19 of the Charter provided that the Tribunal was not bound by strict rules of evidence. Article 21 provided that the Tribunal did not require proof of facts of common knowledge. What exactly could be considered "facts of common knowledge" was not further explained in the Charter. In the context of war, the Tribunal's ability to objectively assess such documents to determine "facts of common knowledge" can be seriously questioned. ${ }^{86}$

The perceived impartiality of the Tribunal is largely due to the efforts of Lord Justice Lawrence to make it so. Lord Justice Lawrence ruled the Tribunal from the Bench, and was above all focused on ruling fairly and impartially. ${ }^{87}$ Historical and legal consensus remains that Lord Justice Lawrence created the distinct impression and atmosphere of impartiality on the Tribunal Bench. ${ }^{88}$ This was a conscious effort on Lord Justice Lawrence's behalf: 89

If Lawrence was thought to have erred in giving too much scope to a defendant, then he would have felt he had erred on the right side; better to shoulder some personal criticism than have the whole trial dismissed as partial to the prosecution.

Lord Justice Lawrence was determined to ensure the trial remained impartial, insisting on evenhandedness throughout. ${ }^{90}$ It has been argued that Lord Justice Lawrence in fact "bent over backwards" to ensure the defendants were given an equal opportunity to present their defences. ${ }^{91}$ This received much criticism from the prosecution, and also from other members of the Tribunal. ${ }^{92}$ Lord Justice Lawrence's dedication to remaining impartial was evident during cross-examination.

85 Harris, above n 16, at 500; Maley, above n 38, at 10.

86 Chenivesse and Piranio, above n 52, at 408.

87 Marrus, above n 1, at 254.

88 Maley, above n 38, at 6; Marrus, above n 1, at 254.

89 Ann Tusa and John Tusa The Nuremberg Trial (Macmillan London, London, 1983) at 290.

90 Marrus, above n 1, at 254.

91 Smith, above $\mathrm{n} 30$, at $102-103$.

92 Smith, above n 30, at 102-103 and 109. 
Justice Jackson's cross-examination of Reich Marshal Goering is one of the most discussed moments of the trial. Jackson was noticeably irritated by Goering's lengthy responses, and argued that he was unnecessarily prolonging the trial. Jackson requested that Goering be limited to "yes/no" answers to the questions. Lord Justice Lawrence intervened on behalf of Goering, stating: ${ }^{93}$

Mr. Justice Jackson, the Tribunal thinks the witness ought to be allowed to make what explanation he thinks right ... after having given a direct answer to any question, he may make a short explanation; and that he is not to be confined simply to making direct answers 'yes' or 'no'.

Goering proceeded to speak relatively uninterrupted for nine days. This cross-examination was valuable insofar as it revealed the Tribunal's impartiality. ${ }^{94}$ Arguably, Lord Justice Lawrence's dedication to remaining impartial throughout the trial was the most successful means of securing the defendants' due process rights. His impartiality operated to relieve the suspicions of defence counsel that the Tribunal and Charter were established solely for the purpose of convicting the defendants. ${ }^{95}$

Francis Biddle also strived to remain impartial. Justice Jackson argued that the Court should not set up its own administrative body, but should work hand-in-hand with the prosecution administration. Biddle was strongly opposed to this suggestion, arguing that to maintain independence and impartiality, it was imperative that the Tribunal ran a separate administration. Justice Jackson disagreed, stating that this was not an ordinary trial, and remnants of independence and impartiality had been dismissed when Nikitchenko had exercised a role in drafting the Charter and later sat on the Tribunal Bench. As Biddle had acted in a similar dual capacity, he was thus even more determined to remain impartial. ${ }^{96}$

Critics have argued that Lord Justice Lawrence almost over-compensated in ensuring impartiality on the part of the Tribunal. Few Germans doubted the impartiality and objectivity of the Judges. In fact, it has been argued that the majority was of the opinion that objectivity was carried too far. ${ }^{97}$ Following Justice Jackson's unsuccessful cross-examination of Goering, Jackson arranged a private meeting with Biddle, during which he accused the members of the Tribunal of always ruling in favour of the defendants. ${ }^{98}$ This allegation suggests that Jackson was concerned about the Judges over-compensating in an effort to remain impartial.

93 Nuremberg Trial Proceedings (20 March 1946) vol 9 at 511.

94 Tusa and Tusa, above n 89, at 291.

95 Maley, above $\mathrm{n} 38$, at 6.

96 Smith, above n 30, at 77.

97 Lueders, above n 82, at 135.

98 Smith, above n 30, at 109. 
Further, the Tribunal produced three acquittals. For a guilty verdict, three out of four votes were required. This suggests that most of the Judges did not have preconceptions regarding the guilt of the defendants, and ruled solely on the evidence put before them. Such a lack of prejudice in the judgments is further evidence of the Tribunal's impartiality.

Therefore, the efforts of Lord Justice Lawrence contributed to the impartiality of the Tribunal. However, its impartiality can be questioned insofar as the preconceptions of Major General Nikitchenko and the evidentiary leniencies are concerned.

\section{THE RIGHT TO ADEQUATE TIME AND FACILITIES TO PREPARE AND PRESENT A DEFENCE}

\section{A History and Development}

The right to adequate time and facilities to prepare and present a defence is a central right accorded to criminal defendants in both Anglo-American and Continental European jurisdictions. The fundamental right of audi alteram partem provides that no defendant shall be judged without the opportunity to present their case and respond to the evidence given against them. ${ }^{99}$ This is consistent with the above principle of equality of arms.

What is considered to be "adequate" time to prepare a defence is very case specific, and it is impossible to set a universally applicable standard. ${ }^{100}$ The post-war context and ad hoc Tribunal could arguably be factors influencing what is considered to be "adequate" time. "Facilities" broadly encompasses four elements: the right of access to the case file, the right of discovery, the discovery of "hidden material" and investigation by the defence. ${ }^{101}$ In theory, the prosecution is under an obligation to disclose all material evidence that is relevant to the defendant's case. ${ }^{102}$

American rules of evidence are stricter and more extensive than European evidential law. Most Continental jurisdictions have flexible rules of evidence, and operate an "inquisitorial" system. ${ }^{103}$ An inquisitorial system places "singular importance on ascertaining the truth at trial", and thus "erects few evidentiary barriers that restrict the information the Judge can consider in determining

99 D J Hewitt Natural Justice (Butterworths, Wellington, 1972) at 120; Bernard Schwartz and HWR Wade Legal Control of Government: Administrative Law in Britain and the United States (Oxford University Press, London, 1972) at 107.

100 Zahar and Sluiter, above n 19, at 308.

101 At 308.

102 Helen Fenwick Civil Liberties and Human Rights (4th ed, Routledge-Cavendish, Oxon, 2007) at 64; Feldman, above n 52, at 678-679; Zahar and Sluiter, above n 19, at 308.

103 Haveman, above n 11, at 114-115. 
guilt". ${ }^{104}$ This can be contrasted with the Anglo-American adversarial process. Hearsay proof is accepted under German law. ${ }^{105}$

\section{B Application and Extent to which the Right was Breached at Nuremberg}

The limited time granted to the defendants to prepare their defence and the barriers they faced in accessing the necessary evidence to prepare those defences is arguably one of the grossest breaches of due process rights at Nuremberg. However, the defendants' right to present their defences and the ability to cross-examine witnesses were generally upheld, with the exception of ex parte witness affidavits.

The Charter had loose evidentiary rules, which were more akin to Continental European legal procedure. As discussed, art 19 of the Charter provided that the Tribunal was not to be bound by technical rules of evidence, and was at liberty to admit any evidence which it deemed to have "probative value". Article 16 provided safeguards to the defendants. Under the Charter, the defendants had to be served with the indictment in German at a reasonable time before the trial, and had the right to access a translation of the trial. ${ }^{106}$ The defendants had the right to give any explanation relevant to the charges made against him. ${ }^{107}$ The defendants had the right to counsel, and through that counsel had the right to present evidence at the trial to support his defence, and also had the right to cross-examine any witnesses called by the prosecution. ${ }^{108}$

The prosecution had in their possession an enormous quantity of German documentation to use as evidence in the trial. A group of military personnel established by the Allies were tasked with seizing and preserving all material German documents, records and archives in preparation for the trial. ${ }^{109}$ By November 1945, the prosecution had over 17,000 pages of oral evidence, and over 22,000 pages of written evidence. ${ }^{110}$ The prosecution subsequently submitted approximately 12,000-15,000 pages to the Tribunal. ${ }^{111}$

104 At 159.

105 Ferencz, above n 69, at 149.

106 Article 16.

107 Article 16.

108 Article 16.

109 Haensel, above n 60, at 256.

110 Krieg, above n 7, at 7.

111 Hans Laternser "Looking Back at the Nuremberg Trials" in Guenael Mettraux (ed) Perspectives on the Nuremberg Trial (Oxford University Press, New York, 2008) 473 at 475. 
The defendants were granted 30 days of preparation from the serving of the indictment to the opening of the trial. 30 days was inadequate, given the "documentary avalanche"112 of evidence that the prosecution had gathered leading up to the trial that had to be examined by defence counsel, the time the defence counsel had to spend getting acquainted with the unfamiliar procedural system, and the barriers faced by the defence counsel in accessing evidence crucial to the defence case. 30 days of preparation inevitably became 21, when 12 defendants had not secured counsel three weeks prior to the trial. ${ }^{113}$

One of the grossest deprivations of due process rights was the defendants' lack of access to evidence held by the prosecution prior to the trial. This is a direct denial of the right to adequate facilities to prepare a defence. The prosecution had thoroughly searched the German archives, and had seized all evidence relevant to the case. Remaining documents (of which there were few) were left for the defence. ${ }^{114}$ Such evidence was gathered and held in limited access document centres. Even some of the most crucial and exonerating material held by the prosecution was not made available to the defence. ${ }^{115}$ Occupying authorities barred the access of defence counsel to the necessary document archives, and they were unable to make the investigations necessary to form their defences. ${ }^{116}$ Even while the trial was in progress, access to material documentation remained difficult for the defence. ${ }^{117}$

The defence also faced difficulties accessing books and information from overseas. It was impossible for the defence to access a copy of the Foreign Minister of Romania and Ambassador to the Soviet Union's article detailing the events leading up to the German invasion of the Soviet Union. ${ }^{118}$ Similarly, the defence was denied access to a copy of General George Marshall's final war report, which was available in Allied newspapers. ${ }^{119}$ Arguably, it would have been possible for the defendants to somehow gain access to this report. However, this demonstrates the additional

112 Smith, above $\mathrm{n} 30$, at 82 .

113 Conot, above n 28, at 81.

114 Kranzbuhler, above n 2, at 436; Laternser, above n 111, at 475.

115 Gerry Simpson Law, War and Crime: War Crimes Trials and the Reinvention of International Law (Polity Press, Cambridge, 2007) at 115; Laternser, above n 111, at 476.

116 Nuremberg Trial Proceedings (23 November 1945) vol 2 at 214; Kranzbuhler, above n 2, at 436; Haensel, above n 60, at 256; Smith, above n 30, at 82; Marrus, above n 1, at 248; Freda Utley The High Cost of Vengeance (Henry Regnery Company, Chicago, 1949); Davidson, above n 31, at 31; Maser, above $n$ 26, at 96.

117 Davidson, above n 31, at 35.

118 Grigore Gafencu "Politics, A Warning Cry: Prelude to the Russian Campaign" (May 1946) in Davidson, above $n 31$, at 34 .

119 Davidson, above n 31, at 34. 
obstacles defence counsel had to overcome when preparing the defence case, and the reluctance of the prosecution to provide the defence with the necessary evidence. In one instance, the prosecution disclosed documents to the press which they had neglected to provide translated copies of to the defence. Biddle and Lord Justice Lawrence viewed this as a direct breach of Court orders. ${ }^{120}$

The lack of access to documents was often as a result of the deliberate withholding of evidence by the prosecution. Initially, Justice Jackson indicated the willingness of the prosecution to make evidence available to the defence. When the Tribunal directed him to do so, he was reluctant to assist the defence. ${ }^{121}$ Before the defence could access any documentary evidence, the prosecution ordered that counsel must first state what they were looking for and then make a specific request. No indexes or summaries were provided; therefore without knowing what the documents contained, defence counsel were unable to make any sort of specific request. ${ }^{122}$ When defence counsel did request copies of documents from the prosecution, they had often "disappeared", or were made available in insufficient quantities, incomplete, not translated and days too late. ${ }^{123}$ During the trial, Justice Jackson suggested that the defence should not be permitted to read its documents into the records, and instead should be limited to submitting the document books to the Judges. Dr Dix (counsel for Hjalmar Schacht) addressed the Court in response: ${ }^{124}$

I cannot consider it just and I cannot consider it fair if the prosecution had the right, for months, not only once but sometimes repeatedly and often, to bring their evidence to the knowledge of the public... The defence counsel must and would consider it a severe and intolerable limitation of the defence, if, contrary to the procedure exercised so far by the prosecution, it were deprived of the possibility of presenting, in its turn, at least the relevant parts of its own documentary evidence to the Tribunal verbally and with comments.

The Judges ruled against Jackson and in favour of the defendants. ${ }^{125}$

As a result of the flexible evidential rules, the Tribunal accepted ex parte witness affidavits from the prosecution, depriving the defendants the right of cross-examination. While the Charter expressly gave defendants the right of cross-examination, it did not prevent the prosecution from introducing ex parte affidavits. Often, the people who wrote the affidavits were unavailable to testify during the trial, denying the defence the right to cross-examine any witnesses. ${ }^{126}$ Witnesses

120 Smith, above n 30, at 84 .

121 At 78.

122 Davidson, above n 31, at 31.

123 Maser, above n 26, at 98.

124 Nuremberg Trial Proceedings (22 March 1946) vol 9 at 661.

125 Nuremberg Trial Proceedings (22 March 1946) vol 9 at 672.

126 Haveman, above n 11, at 273. 
were often unwilling to personally testify before the defendants and the Tribunal, or were practically unable to (many were in jail and others lived a great distance from Nuremberg). ${ }^{127}$ The Tribunal accepted such affidavits despite objections from defence counsel. ${ }^{128}$ Depriving the defendants this right to cross-examine witnesses is a direct denial of their rights to present a defence, and thus a gross breach of their due process rights.

Further, the defendants were faced with language and translation difficulties, which exacerbated the time pressures in preparing the defence case. When the defence requested copies of documentation from the prosecution, they were often provided only in English. ${ }^{129}$ Once the documents were eventually translated, errors were found. ${ }^{130}$

Lord Justice Lawrence acknowledged the weaknesses of the defence in terms of the time and facilities available to prepare their cases, and made some efforts to mitigate these inadequacies. On 22 November 1945, assistant trial counsel for the United States, Frank Wallis, was discussing sections of the indictment. Lord Justice Lawrence stopped Wallis, and ordered that before he be allowed to continue, he must make available translated copies to the defence counsel. ${ }^{131}$ Further, Dr Dix addressed the Tribunal regarding the difficulties they were facing in terms of having adequate time and facilities to prepare their defences, given the unfamiliar Anglo-American procedures. Lord Justice Lawrence ruled in favour of the defence. The Tribunal ordered that to be accepted into evidence, every prosecution document must go through a four-language translation system, and the process must give defence counsel adequate time to object. ${ }^{132}$

However, the Tribunal members had the authority to refuse to accept defence evidence, which infringed on their rights to present a defence. Defence counsel were under the obligation to inform the Judges of any evidence to be presented by the defence. Under the Charter, the Judges could refuse to accept the evidence into the trial if they ruled it did not have practical "relevance". ${ }^{133}$ This was a wide discretion given to the Judges as a result of the flexible evidential rules, leaving the rules open to abuse, ultimately to the disadvantage of the defence. While Lord Justice Lawrence was thorough in explaining this procedure to the defence, it did little to help them. ${ }^{134}$

127 Utley, above n 116.

128 Michael P Scharf "Have We Really Learned the Lessons of Nuremberg?" (1995) 149 Mil L Rev 65 at 69.

129 Maser, above n 26, at 98; Kranzbuhler, above n 2, at 442-443.

130 Laternser, above n 111, at 481 .

131 Nuremberg Trial Proceedings (23 November 1945) vol 2 at 214.

132 Smith, above n 30 , at 84 .

133 Article 20; Utley, above n 116; Davidson, above n 31, at 32.

134 Davidson, above n 31, at 32. 
The lack of time granted to the defendants to prepare a defence, the lack of access to necessary documentary evidence, the translation difficulties, abuse of flexible evidentiary rules and acceptance of ex parte affidavits in conjunction operated to deprive the Nuremberg defendants of the adequate time and facilities to prepare and present a defence.

\section{THE RIGHT OF APPEAL TO A HIGHER COURT OR TRIBUNAL}

\section{A History and Development}

The right to appeal a case to a higher court or tribunal is recognised and protected in both Continental and Common Law jurisdictions. The right of appeal has a complex history. Criminal appeal rights in Continental Europe can be traced back to Roman times. ${ }^{135}$ In contrast, the modern right of criminal appeal was not formally recognised in Anglo-American jurisdictions until the turn of the 20th century. ${ }^{136}$ The right of appeal has thus developed over time, and has only recently been recognised as a fundamental due process right. However, it is often only the right to a limited appeal. In the United States and England, the appealed case is not looked at completely anew. ${ }^{137}$ The broad right of appeal is not present in the United States Bill of Rights. ${ }^{138}$

The right of appeal is considered fundamental because it provides an opportunity for potential errors made in the first instance to be corrected. Particularly in a post-war international context, the right of appeal is a crucial means of mitigating potential prejudice and bias.

Appeal rights are a means of preventing miscarriages of justice and securing the legitimacy of the criminal justice process. ${ }^{139}$ Appeal processes also operate to achieve consistency in trial courts, though arguably this is inapplicable in the context of ad hoc international military courts without a jury.

\section{B Application and Extent to which the Right was Breached at Nuremberg}

Article 26 of the Charter provided that the judgment of the Tribunal as to guilt or innocence shall give reasons, and shall be final and not subject to appeal or review. The right of appeal was altogether denied: there was no appellate instance to neither affirm nor reject the judgments or

135 Peter D Marshall "A Comparative Analysis of the Right to Appeal" (2011) 22 Duke J Comp and Intl L 1 at 11; Mirjan Damaska "Structures of Authority and Comparative Criminal Procedure" (1975) 84 Yale L J 480 at 489.

136 Marshall, above n 135, at 4.

137 Haveman, above n 11, at 122.

138 At 122.

139 Marshall, above n 135, at 2. 
sentences. In the interests of time and expense, the Allies desired a full and final judgment. ${ }^{140}$ Deprivation of this fundamental right to have the Nuremberg judgments evaluated at a higher appellate level has been considered one of the most "procedurally dubious" and controversial elements of the trial. ${ }^{141}$

Given the unique historical and political context, an appellate instance was not entirely practicable. Justice Jackson and the other Allies agreed that in the context of a trial of a "tiny number of notorious men who had dominated the world stage for a dozen years", an appellate Tribunal was impractical and unnecessary. ${ }^{142}$ Realistically, it is difficult to see where any reasonable appeal could have been made.

However, the defendants in the subsequent Nuremberg trials were given rights of appeal, although these rights were limited. Arguably, this was a direct result of the criticism voiced in response to the IMT defendants receiving no appeal rights. The defendants were permitted to appeal to the United States Military Governor. ${ }^{143}$ They were given the right to seek clemency and pardons based on: first, a review of the evidence against them; secondly, any legal issues; and thirdly, personal circumstances. ${ }^{144}$ While often viewed as political mechanisms, these "appellate" procedures benefited a large portion of defendants. ${ }^{145}$

The right of appeal is vigorously protected by contemporary international standards. ${ }^{146}$ Critics accept that it would have added complexity to the trials, but that "justice demands it". ${ }^{147}$ Given that the Tribunal permitted trial in absentia, in conjunction with the ability of the Tribunal to award a death sentence, ${ }^{148}$ the fact that the defendants had no right of appeal was particularly unjust in these circumstances. The potential partiality and lack of independence of the Judges was unable to be mitigated by appeal to a neutral authority, or even another legal figure of the Allied nations. While there is no knowing whether the convictions or sentences would have been overturned or even lessened, the absence of such an opportunity greatly diminishes the chance of the Nuremberg trial being judged as just.

140 Krieg, above n 7, at 7.

141 Simpson, above n 115, at 115; Jonathan A Bush "Lex Americana: Constitutional Due Process and the Nuremberg Defendants" (2001) 45 St Louis U LJ 515 at 530.

142 Bush, above n 141, at 531.

143 Utley, above n 116.

144 Bush, above n 141, at 531.

145 At 531 .

146 Chenivesse and Piranio, above n 52, at 408.

147 Wallach, above n 14, at 883.

148 Article 27. 


\section{CONCLUSION}

The Nuremberg Trial at the IMT was the first international tribunal established for the punishment of war crimes, and has provided a model for later ad hoc tribunals and the more permanent International Criminal Court. While the trial has often been praised for laying the foundations for subsequent international criminal tribunals, Nuremberg's adherence to procedural due process can be extensively criticised.

Given the circumstances of the trial and the limited practical alternatives available, the Nazi defendants were arguably afforded more due process rights than they could have expected. Justice Jackson aptly recognised this at the close of the trial: ${ }^{149}$

The future will never have to ask, with misgiving, what could the Nazis have said in their favour.

History will know that whatever could be said, they were allowed to say. They have been given the kind

of a Trial which they, in the days of their pomp and power, never gave to any man.

The Tribunal partially protected the defendants' right to be represented by counsel. However, notwithstanding its express protection in the Charter, Hess was directly denied the right to act as his own counsel, in breach of this fundamental right. The Tribunal protected the defendants' right to a public hearing by ensuring that all hearings were conducted publically. The Tribunal at Nuremberg was far from independent, though due to the efforts of Lord Justice Lawrence, this did not detract substantially from its ability to remain impartial. Similarly, the efforts of the Judges to mitigate the inequalities between the prosecution and the defence are direct evidence of the Tribunal's determination to secure an equal (and thus fair) trial for the defendants.

The grossest breach of the defendants' due process rights lay in the deprivation of adequate time and facilities to prepare and present a defence. The lack of time granted to the defendants to prepare a defence, the lack of access to necessary documentary evidence, the translation difficulties, abuse of flexible evidentiary rules and acceptance of ex parte witness affidavits in conjunction operated to deprive the Nuremberg defendants of this fundamental due process right.

The second major breach of due process was the inability of the defendants to appeal the judgments and sentences to a higher appellate body. The fact that the Tribunal (whose independence can be genuinely questioned) allowed defendants to be tried in absentia, in addition to the ability of the Tribunal to award the death sentence made the lack of appellate instance particularly unjust.

The due process rights of the 22 defendants were partially protected at Nuremberg. The right to represent oneself, the right to properly prepare and present a defence and the right of appeal are pivotal due process rights that are recognised and protected internationally; however, they were not protected at Nuremberg. These gross breaches of fundamental due process rights operated to compromise the integrity of the trial.

149 Nuremberg Trial Proceedings (26 July 1946) vol 19 at 398. 